\title{
Intellectual Leadership of Researchers in Higher Education: Relationship Between the Demographic Factors and Roles (Lithuanian Context)
}

\author{
Vilma Žydžiūnaitè ${ }^{*}$ \\ Received: July 4, 2016; received in revised form: September 28, 2016; \\ accepted: October 3, 2016
}

\begin{abstract}
The intellectual leadership of educators or teachers represents a topic of a great interest for educational research and practice. Variety of variables or factors have been examined to find the most complete explanations for teachers', professors' and educators' roles, for example, institutional, financial, gender, organizational, spiritual, and intellectual. No literature was found on the relationship between the demographic variables and researchers' roles in higher education regarding intellectual leadership. But a lot of studies are focused on the relationship between demographic and other factors in education: job satisfaction, organizational justice, religion, gender, culture, personal and professional roles, stress, mental health, and mobility. The research issue in this study is related to researchers'/scientists' work in higher education schools and is focused on intellectual leadership, which consists of different roles. It is worth to think about researchers as intellectual leaders and to discover how they recognize or identify their roles in higher education. In this study, findings answer the following research question: "What are the relationships between researchers' roles and their gender, work experience, dissertation defence date, and research field?" The object of the research study is the researchers' roles in higher education. The aim of the study was to reveal the relationship between demographic factors and researchers' roles in higher education. Data were collected by performing a questioning survey and using a validated questionnaire with 116 statements in total. The sample consisted of 304 researchers working in higher education institutions. For data analysis, Cronbach's alpha, Mean and ANOVA calculations were used. The research findings reported that the female-researchers' evaluations were higher in all cases regarding their
\end{abstract}

Vilma Žydžiūnaite, Department of Education, Vytautas Magnus University, Kaunas, Lithuania; vilma.zydziunaite@vdu.lt 


\section{Acta Technologica Dubnicae \\ volume 6, 2016, issue 3}

roles in higher education schools. The results of the study highlighted that the male-researchers were devoted to the roles of academic citizens and mentors, while they did not refer the interest for academic freedom and the role of a knowledge producer. Findings revealed that the role of an academic citizen is perceived equally to other roles, despite the fact that researchers work in different research fields. In this research study, the highest estimates were given to the roles by the researchers representing medical sciences. Results showed that the lowest estimates for the diverse roles in higher education were provided by the researchers from engineering sciences. A correlation analysis between distinguished minor roles descriptions revealed that the participation of scientists in society debates and public policy correlates with all the remaining roles of scientists very weakly or weakly. The strongest correlation with all roles refers to academic duty, critic, personal development, and acting in one research field. In conclusion, intellectual leadership is the scope of challenging processes regarding developing, designing, creating, defining, ensuring, critiquing, teaching, instructing, researching, mentoring, enabling questioning, generating, envisioning, advocating, encouraging, re-imagining, managing, representing, counseling, achieving, evaluating, acting, and providing. The general components here refer to ideas, values, understandings, solutions, beliefs, visions, knowledge, approaches, purposes, and actions. By concluding the study, it is worth to accentuate that the demographic factors that are meaningful in studying the researchers' roles within the intellectual leadership in higher education are the following - gender and research areas. The work experience in higher education and the year of Ph.D. defence are not the factors, which are meaningfully related to the role performance, academic duty and academic freedom of the researcher as an intellectual leader in higher education.

Key words: gender, higher education, intellectual leadership, researcher, role, scientific field.

\section{Introduction}

The role of a researcher in higher education as a public good continues to be fundamentally important. This aspect of higher education is easily neglected in the rush for income and prestige (Altbach et al., 2009). Researchers are an essential human resource in universities and colleges to achieve the higher education missions effectively. Hence, researchers are expected to carry out many duties and have many responsibilities such as leading research, producing income, preserving scientific and professional standards, helping their colleagues in career advancement, being a role model, influencing public debates, influencing the university's direction and representing their department and/or university (Uslu \& Arslan, 2015). These behaviors and activities exhibited by academics while fulfilling their duties and responsibilities are termed as intellectual leadership (Macfarlane, 2011, 2012). Researchers as 


\section{Acta Technologica Dubnicae \\ volume 6, 2016, issue 3}

intellectual leaders have a double duty: to continue in practicing their science or art as individuals (and groups) and to nurture others who will extend and challenge their ideas. They will be assisted - or hindered - by the culture and climate created by the higher education institution in which they are located. Individual academics at all levels in higher education institution have the potential to exercise intellectual leadership through the power of their ideas promulgated in the classroom, laboratory, seminal texts or other media. In practice, higher education institutions promote intellectual leadership through academic channels: researchers can shape the culture through disciplines and academic processes (Macfarlane, 2010).

The intellectual leadership of educators or teachers represents a topic of a great interest for educational research and practice. Variety of variables or factors had been examined to find the most complete explanations for educators', teachers' or professors' roles: institutional (Pinfield \& Middleton, 2016), institutional and financial (Justice \& Scott, 2012), gender and organizational (Georgeta, 2014), spiritual (Nickles, 2011), and intellectual (Taylor \& Parsons, 2011). No literature was found on the relationship between demographic variables and researchers' roles in higher education regarding intellectual leadership. But a lot of studies are focused on the relationship between demographic and other factors in education: job satisfaction, organizational justice, religion, gender role beliefs, and culture, gender, personal and professional roles, stress and mental health, and mobility for industrial innovation.

The research issue in this study is related to researchers'/scientists' work in higher education schools and is focused on intellectual leadership, which consists of different roles. It is worth to think about researchers as intellectual leaders and to discover how they recognize or identify their roles in higher education. In this study, findings answer the following research question: "What are the relationships between researchers' roles and their gender, work experience, dissertation defence date, and research field?" The object of the research study is the researchers' roles in higher education. The aim of the study was to reveal the relationship between demographic factors and researchers' roles in higher education.

\section{Roles of researchers in higher education}

The term researcher refers to being engaged, acting and performing a careful study at a university or college. Researchers should have skills that are needed to perform research, i.e. intellectual and leadership skills (Sugarman, 2005) (see Table 1). 


\section{Acta Technologica Dubnicae \\ volume 6, 2016, issue 3}

Table 1

Explanation of the terms "research" and "researcher" in dictionaries

\begin{tabular}{ll}
\hline \multicolumn{1}{c}{ Dictionary } \\
$\begin{array}{l}\text { The Free Dictionary } \\
\text { by Farlex (2016) }\end{array}$ & $\begin{array}{l}\text { Research: 1) careful study of a given subject field, or } \\
\text { problem, undertaken to discover facts or principles; 2) } \\
\text { an act or period of such study; 3) to engage in or } \\
\text { perform research; 4) to study (something) thoroughly } \\
\text { so as to present in a detailed, accurate manner; 5) to do } \\
\text { research for. } \\
\text { Researcher: is someone who conducts research, i.e. an } \\
\text { organized and systematic investigation into something. }\end{array}$ \\
Dictionary.com (2016) & $\begin{array}{l}\text { [Synonyms - investigator, researcher worker, } \\
\text { scientist.] }\end{array}$ \\
Researcher: someone whose job is to study a subject \\
carefully, especially in order to discover new \\
$\begin{array}{l}\text { Dictionaries Online } \\
\text { (2016) }\end{array}$
\end{tabular}

Researchers at universities and/or colleges work in relation to academic duties and freedom. Academic duty and academic freedom are the two sides of the same coin (Kennedy, 1997) and both are related to researchers' roles under the intellectual leadership at a university and/or college. Academic freedom is about the freedom of thought and expression essential to creativity and criticism (Macfarlane, 2012). Researchers should follow their duties at universities or colleges with a focus on teaching, service and research (Theall \& Arreola, 2003; Grayson, 2016) (see Table 2).

Table 2

Duties of a researcher in higher education

\begin{tabular}{lll}
\hline $\begin{array}{l}\text { Teaching } \\
\text { Prepare lectures, syllabi, } \\
\text { labs for classes }\end{array}$ & $\begin{array}{l}\text { Advise students regarding } \\
\text { course selection }\end{array}$ & $\begin{array}{l}\text { Write grant proposals } \\
\text { for submission to } \\
\text { funding agencies } \\
\text { Grade class assignments }\end{array}$ \\
$\begin{array}{lll}\text { Counsel students on } \\
\text { career opportunities and } \\
\text { choices }\end{array}$ & $\begin{array}{l}\text { verifiable and } \\
\text { publishable scholarly } \\
\text { research }\end{array}$ \\
$\begin{array}{l}\text { Prepare, give make-up } \\
\text { and grade exams }\end{array}$ & $\begin{array}{l}\text { Write recommendations } \\
\text { for students seeking jobs } \\
\text { and applying to graduate } \\
\text { schools }\end{array}$ & $\begin{array}{l}\text { Monitor spending from } \\
\text { grants obtained from } \\
\text { funding agencies }\end{array}$ \\
\hline
\end{tabular}




\begin{tabular}{|c|c|c|}
\hline Calculate grades & Edit academic journals & $\begin{array}{l}\text { Maintain laboratories } \\
\text { for faculty and student } \\
\text { research }\end{array}$ \\
\hline $\begin{array}{l}\text { Meet with students } \\
\text { outside class for help }\end{array}$ & $\begin{array}{l}\text { Review papers submitted } \\
\text { to academic journals and } \\
\text { grant proposals submitted } \\
\text { to funding agencies }\end{array}$ & $\begin{array}{l}\text { Write papers for } \\
\text { publication in academic } \\
\text { journals }\end{array}$ \\
\hline $\begin{array}{l}\text { Integrate new learning } \\
\text { into existing classes }\end{array}$ & $\begin{array}{l}\text { Serve on review } \\
\text { committees of funding } \\
\text { agencies and on } \\
\text { departmental committees }\end{array}$ & $\begin{array}{l}\text { Present research at } \\
\text { meetings of scholarly } \\
\text { societies to promote the } \\
\text { university }\end{array}$ \\
\hline Develop new classes & $\begin{array}{l}\text { Serve on committees and } \\
\text { in elected positions of } \\
\text { scholarly societies }\end{array}$ & $\begin{array}{l}\text { Give presentations in } \\
\text { other institutions within } \\
\text { the higher education }\end{array}$ \\
\hline $\begin{array}{l}\text { Supervise and evaluate } \\
\text { graduate student teaching }\end{array}$ & $\begin{array}{l}\text { Participate in } \\
\text { departmental faculty } \\
\text { meetings and } \\
\text { departmental retreats }\end{array}$ & $\begin{array}{l}\text { Read scholarly journals } \\
\text { with the focus on new } \\
\text { developments }\end{array}$ \\
\hline $\begin{array}{l}\text { Evaluate teaching by } \\
\text { colleagues }\end{array}$ & $\begin{array}{l}\text { Serve in departmental } \\
\text { administrative positions }\end{array}$ & \\
\hline Lead the field trips & $\begin{array}{l}\text { Participate in or host } \\
\text { faculty searches }\end{array}$ & \\
\hline $\begin{array}{l}\text { Attend department } \\
\text { colloquia }\end{array}$ & $\begin{array}{l}\text { Serve in Faculty Senate } \\
\text { and/or College or } \\
\text { University Council }\end{array}$ & \\
\hline $\begin{array}{l}\text { Supervise graduate } \\
\text { student research }\end{array}$ & $\begin{array}{l}\text { Respond to information } \\
\text { requests from } \\
\text { administrators }\end{array}$ & \\
\hline $\begin{array}{l}\text { Help graduate students } \\
\text { with their research }\end{array}$ & $\begin{array}{l}\text { Serve on university } \\
\text { committees }\end{array}$ & \\
\hline $\begin{array}{l}\text { Read, make suggestions } \\
\text { to improve, and evaluate } \\
\text { graduate student thesis } \\
\text { proposals, MS student } \\
\text { theses and Ph.D. student } \\
\text { dissertations }\end{array}$ & $\begin{array}{l}\text { Participate in university's } \\
\text { convocations }\end{array}$ & \\
\hline Read and evalute written & Participate in & \\
\hline $\begin{array}{l}\text { PhD comprehensive } \\
\text { exams }\end{array}$ & Commencement exercises & \\
\hline $\begin{array}{l}\text { Participate in Ph.D. oral } \\
\text { comprehensive exams }\end{array}$ & $\begin{array}{l}\text { Respond to public queries } \\
\text { in faculty areas of } \\
\text { specialization }\end{array}$ & \\
\hline
\end{tabular}




\begin{tabular}{ll}
\hline $\begin{array}{l}\text { Participate in graduate } \\
\text { student defences }\end{array}$ & $\begin{array}{l}\text { Perform public service in } \\
\text { faculty areas of } \\
\text { specialization } \\
\text { Give public lectures }\end{array}$ \\
\hline
\end{tabular}

The duties of a researcher are related to activities, which require intellectual leadership and empowerment (Theall, 2002; Theall \& Arreola, 2003; Sugarman, 2005), for example, supervising, leading, making suggestions, developing, and counseling (see Table 2).

Universities or colleges have rules and regulations, which outline the steps to move up the ladder to the implementation of the researchers' roles in higher education. Usually, the researchers' roles are the following (Grayson, 2016):

- Teaching. Researchers must mentor students in laboratory or research centers, even though the instructors aren't assigned to a class.

- Scholarship. Researchers must publish scholarly articles in journals and magazines recognized by experts as high-quality publications.

- Service. Researchers volunteer for committee work, chairing projects, attending meetings and work with student groups as faculty advisers. The amount of service required from researchers varies with universities, colleges and the departments.

Macfarlane (2011, 2012) and Macfarlane and Chan (2014) described researchers' roles in regard to their intellectual leadership in higher education. The particular roles of researchers by implementing intellectual leadership in higher education are the following: a mentor, an advocate, a guardian, an enabler, an ambassador, a knowledge producer, an academic citizen, a boundary transgressor, a public intellectual, and a critic:

- Mentor indicates contributing to the development of less experienced colleagues by guiding and facilitating their scholarly activities, and nurturing their potential by collaborative studies.

- Advocate designates the following aspects: i) emphasizing the importance of a discipline and contributing its value by benefiting from disciplinary expertise in institutional services, ii) applying theoretical information and practical experiences based on their scholarly activities to the solution of social problems. Researchers as advocates should influence public debates by transferring their knowledge, ideas and suggestions to people via local, national and international levels by adapting theoretical understandings of their disciplines.

- Being a guardian means to keep up academic values and standards in scholarly platforms and contribute to the development of scientific fields in 


\section{Acta Technologica Dubnicae \\ volume 6, 2016, issue 3}

new directions by unprejudiced peer review activities. When researchers become more experienced and well-known in their field, their guardianship roles start to increase with new roles in different editorial boards, scientific committees and research councils besides promoting academic titles.

- Enabler implies that researchers should acquire research grants, research and development contracts, patents and copyrights as an indispensable part of the reality of contemporary colleges and universities. Being an enabler covers supporting young researchers and junior colleagues and their research initiatives financially by coordinating and leading project teams to obtain research funds. Researchers are also important figures in establishing communication channels between younger researchers, effective faculty and academic leaders in their discipline from inside and outside of their higher education institutions.

- The role of an ambassador emphasizes the representation of higher education institutions and their interests by researchers in local, national and even international platforms. When researchers become more wellknown figures in academia nationally and internationally, they can contribute more fully to the reputation of their institutions.

- Knowledge producers are seeking to have an impact on theory and/or practice through the creation of propositional or professional knowledge, through new theories, frameworks, critiques, analyses, models and discoveries.

- Academic citizens look to apply their disciplinary and/or professional specialism for the benefit of wider public understanding. They use innovative methods, occupy significant leadership roles and engage in public outreach work.

- Researchers as boundary transgressors seek to challenge the norms of established disciplines, and develop connections across the fields of enquiry through teaching, research and scholarship. Researchers transgress the conventional and enter adjacent academic territories.

- Public intellectuals engage with and seek to influence public debate on social, moral and economic issues through speaking, writing and campaigning.

- Being a critique needs to be understood as taking place in different contexts, from the inner world of the discipline through to the applied and societal context in which disciplines, politics and society intersect. 


\section{Acta Technologica Dubnicae \\ volume 6, 2016, issue 3}

\section{Methodology}

\section{1 Design}

Collection of information refers to quantitative research - a questioning survey. The essence of the survey concerns obtaining "facts in digital expression regarding human behaviour and situations, as well as self-reflection" (Fowler, 1981, p. 2).

\subsection{Sample}

The main sample attribute refers to already awarded doctoral (Ph.D.) degree. According to the data provided by the Department of Statistics of Lithuania, the number of researchers being awarded the Ph.D. degree in Lithuania has reached approximately 8100 in 2014 (http://osp.stat.gov.lt/services-portlet/pub-editionfile?id=3308). In accordance with the simplified Yamane formula (1967, p. 886 ), the sample size refers to $n \approx \frac{N}{1+N(e)^{2}} \approx 269$, herein e - calculation error (this research sample implies 6\% calculation error, $\mathrm{N}=8100$ ).

The simple random sampling was applied in the study by providing the request to fill in the questionnaire for each potential respondent. In total, there were 318 questionnaires filled in, however 14 questionnaires were filled in incompletely, therefore only 304 questionnaires were correct. The research participants have acquired the Ph.D. degree in the period from 1968 to 2015. The main part of the sample consisted of the representatives of social sciences (see Table 3).

Table 3

The defended Ph.D. dissertations within the sample

\begin{tabular}{lcc}
\hline Research areas & $\begin{array}{c}\text { No. of } \\
\text { respondents }\end{array}$ & Percentage \\
\cline { 2 - 3 } Social sciences & 148 & 48.8 \\
Humanities & 39 & 12.8 \\
Engineering sciences & 16 & 5.3 \\
Health sciences & 15 & 4.9 \\
Medical sciences & 12 & 3.9 \\
Technological sciences & 46 & 15.1 \\
Natural sciences & 15 & 4.9 \\
Physical sciences & 13 & 4.3 \\
In total & 304 & 100 \\
\hline
\end{tabular}

The majority of respondents had more than 5 years' experience of working in higher education schools (see Table 4). 


\section{Acta Technologica Dubnicae \\ volume 6, 2016, issue 3}

Table 4

Experience in higher education school

\begin{tabular}{lcc}
\hline Experience in years & $\begin{array}{c}\text { No. of } \\
\text { respondents }\end{array}$ & Percentage \\
\cline { 2 - 3 } Approx. 1 year & 5 & 1.6 \\
1-5 years & 27 & 8.9 \\
6-10 years & 64 & 21.1 \\
11-15 years & 69 & 22.7 \\
16-20 years & 59 & 19.4 \\
> 20 years & 80 & 26.3 \\
In total & 304 & 100 \\
\hline
\end{tabular}

The majority of respondents were $41-45$ years old (62 respondents/20.4\%). The smallest part of sample consisted of 25-30-year-olds (4 respondents/1.3\%) and over 65 -year-olds (12 respondents/3.9\%) participants. Females represented the majority of the research participants (197 respondents/64.8\%).

\subsection{Methods}

Data analysis was based on the applied methods of mathematical statistical analysis using MS Excel and SPSS (Statistical Package for Social Sciences) 22 version. Statistical hypothesis testing was used for type I error - level of significance $=0.05$. Cronbach's alpha was applied for disclosing the internal coherence of the subscale. Coherence is considered to be adequate if Cronbach's alpha exceeds 0.7 (Tavakol \& Dennick, 2011).

Parametric criteria (blocked data ANOVA) were applied with the aim to compare indexes between diverse groups of respondents. Comparison of mean using derivative indicators was applied for evaluation of researchers' roles' importance (roles' prioritising). ANOVA was also applied with the aim to compare the evaluations of roles referring to different demographic indicators: gender, research field, age, and experience.

\subsection{Tool}

The original validated questionnaire (Zydziunaite et al., 2015 a, b) on researchers' roles in higher education was used. The construct of the tool is based on the conception of Macfarlane $(2007,2010,2011,2012)$ on "Intellectual Leadership in Higher Education". The conceptual framework was enriched by other following publications of Dealtry (2001); Rowley and Sherman (2003); Yielder and Codling (2004); Blackmore and Blackwell (2006); Roy et al. (2008); Tseng et al. (2010); and Stevenson (2012). 


\section{Acta Technologica Dubnicae \\ volume 6, 2016, issue 3}

The tool consists of 2 parts, 12 questions and 116 statements in total. The first part of "demography" incorporates 6 questions about the years of Ph.D. defence, academic/research work experience, research areas and subjects, and age. The second part "being an intellectual leader" includes 2 questions about academic duties and freedom with 24 items in total. The third part "researchers' leadership roles in higher education" consists of four questions with 58 items in total.

In the first part, the research participants are asked to choose 'yes' or 'no' regarding every statement. To measure every statement in the second and thirds parts, respondents are asked to use the Likert-type scale ranging from 1 (totally disagree) to 5 (totally agree).

Cronbach's Alpha measures of every part were the following: 0.878 academic freedom; 0.895 academic duty; 0.857 critic; 0.804 mentor; 0.861 knowledge producer; 0.842 academic citizen.

\subsection{Ethics}

During the research, all the respondents received a reference letter explaining the research aim, anonymity of provided information, as well as its application for scientific purposes. An e-mail address was presented for available contact link. The questionnaire was filled-in only by respondents who were willing to participate in the research.

Whereas the questionnaires were shared through the internet, the research group made no impact or pressure on the respondents. There were no requests to provide personal data except particular general demographic information, for example, age, work experience, and research area. The questionnaire was anonymous.

\section{Results}

Comparing evaluations of researchers' roles according to gender, statistically significant differences were found in all cases (ANOVA, see Table 5).

Females' evaluations were higher in all cases. The obvious difference was determined by evaluating academic freedom and academic duty, though less significance was found by evaluating the role of a critic. 


\section{Acta Technologica Dubnicae \\ volume 6, 2016, issue 3}

Table 5

Evaluation of researchers' roles according to gender

\begin{tabular}{|c|c|c|c|c|c|c|}
\hline & & Mean & $\begin{array}{l}\text { Standard } \\
\text { deviation }\end{array}$ & $\frac{\text { Freedom }}{\text { degrees }}$ & $\underline{F}$ & $\mathrm{p}$ \\
\hline \multirow{2}{*}{$\begin{array}{l}\text { Academic } \\
\text { freedom }\end{array}$} & Female & 2.76 & 1.40 & 1 & \multirow[t]{2}{*}{7.587} & \multirow[t]{2}{*}{0.006} \\
\hline & Male & 2.32 & 1.08 & 289 & & \\
\hline \multirow{2}{*}{$\begin{array}{l}\text { Academic } \\
\text { duty }\end{array}$} & Female & 2.81 & 1.18 & 1 & \multirow[t]{2}{*}{6.844} & \multirow[t]{2}{*}{0.009} \\
\hline & Male & 2.45 & 0.95 & 289 & & \\
\hline \multirow[t]{2}{*}{ Critic } & Female & 2.73 & 1.11 & 1 & \multirow[t]{2}{*}{4.095} & \multirow[t]{2}{*}{0.044} \\
\hline & Male & 2.46 & 0.91 & 289 & & \\
\hline \multirow[t]{2}{*}{ Mentor } & Female & 2.78 & 1.02 & 1 & \multirow[t]{2}{*}{5.200} & \multirow[t]{2}{*}{0.023} \\
\hline & Male & 2.50 & 0.92 & 289 & & \\
\hline \multirow{2}{*}{$\begin{array}{l}\text { Knowledge } \\
\text { producer }\end{array}$} & Female & 2.64 & 0.92 & 1 & \multirow[t]{2}{*}{5.781} & \multirow[t]{2}{*}{0.017} \\
\hline & Male & 2.38 & 0.81 & 289 & & \\
\hline \multirow{2}{*}{$\begin{array}{l}\text { Academic } \\
\text { citizen }\end{array}$} & Female & 2.75 & 0.83 & 1 & \multirow[t]{2}{*}{5.349} & \multirow[t]{2}{*}{0.021} \\
\hline & Male & 2.51 & 0.83 & 289 & & \\
\hline
\end{tabular}

If considering just females' evaluation, statistically significant differences were not determined $(p>0.05)$. Meanwhile, evaluation of male was statistically significant (blocked data results' sphericity: Mauchly's $\mathrm{W}=0.433, \chi 2=77.125$, $\mathrm{df}=14, \mathrm{p}=0.000$, mean equals: $\mathrm{F}=3.754, \mathrm{df}=3.761, \mathrm{p}=0.006$ ).

The lowest evaluation was expressed by males referred to academic freedom, the role of knowledge producer, while the highest evaluation was devoted for the roles of an academic citizen and mentor.

Dispersive analysis was applied and the roles among researchers representing different research fields were compared. Results showed that the role of an academic citizen is perceived equally to other roles, despite the fact that the researchers work in different research fields (see Table 6).

The highest estimates were given to the roles by the researchers representing medical sciences. The lowest estimates for the diverse roles (except academic duty) were provided by the researchers from engineering sciences. 


\section{Acta Technologica Dubnicae \\ volume 6, 2016, issue 3}

Table 6

Evaluation of researchers' roles according to the field of research

\begin{tabular}{|c|c|c|c|c|c|c|}
\hline & & Mean & $\frac{\text { Standard }}{\text { deviation }}$ & $\begin{array}{l}\frac{\text { Freedom }}{\text { degrees }} \\
\end{array}$ & $\underline{F}$ & $\mathrm{p}$ \\
\hline \multirow{8}{*}{$\begin{array}{l}\text { Academic } \\
\text { freedom }\end{array}$} & Social sciences & 2.91 & 1.41 & 7 & \multirow{8}{*}{4.370} & \multirow[t]{8}{*}{0.000} \\
\hline & Humanities & 2.25 & 1.22 & 296 & & \\
\hline & $\begin{array}{l}\text { Engineering } \\
\text { sciences }\end{array}$ & 1.94 & 0.77 & & & \\
\hline & Health sciences & 3.72 & 1.32 & & & \\
\hline & Medical sciences & 4.00 & 0.87 & & & \\
\hline & $\begin{array}{l}\text { Technological } \\
\text { sciences }\end{array}$ & 2.12 & 0.90 & & & \\
\hline & Natural sciences & 2.16 & 1.10 & & & \\
\hline & $\begin{array}{l}\text { Interdisciplinary } \\
\text { research }\end{array}$ & 2.41 & 1.33 & & & \\
\hline \multirow{8}{*}{$\begin{array}{l}\text { Academic } \\
\text { duty }\end{array}$} & Social sciences & 2.90 & 1.21 & 7 & \multirow[t]{8}{*}{3.760} & \multirow[t]{8}{*}{0.000} \\
\hline & Humanities & 2.49 & 0.97 & 296 & & \\
\hline & $\begin{array}{l}\text { Engineering } \\
\text { sciences }\end{array}$ & 2.30 & 0.87 & & & \\
\hline & Health sciences & 3.82 & 1.15 & & & \\
\hline & Medical sciences & 4.00 & 0.69 & & & \\
\hline & $\begin{array}{l}\text { Technological } \\
\text { sciences }\end{array}$ & 2.28 & 0.77 & & & \\
\hline & Natural sciences & 2.23 & 0.89 & & & \\
\hline & $\begin{array}{l}\text { Interdisciplinary } \\
\text { research }\end{array}$ & 2.48 & 1.26 & & & \\
\hline \multirow[t]{8}{*}{ Critic } & Social sciences & 2.83 & 1.17 & 7 & \multirow[t]{8}{*}{3.487} & \multirow[t]{8}{*}{0.001} \\
\hline & Humanities & 2.26 & 0.94 & 296 & & \\
\hline & $\begin{array}{l}\text { Engineering } \\
\text { sciences }\end{array}$ & 2.22 & 0.69 & & & \\
\hline & Health sciences & 3.59 & 0.83 & & & \\
\hline & Medical sciences & 3.78 & 0.83 & & & \\
\hline & $\begin{array}{l}\text { Technological } \\
\text { sciences }\end{array}$ & 2.44 & 0.69 & & & \\
\hline & Natural sciences & 2.32 & 0.91 & & & \\
\hline & $\begin{array}{l}\text { Interdisciplinary } \\
\text { research }\end{array}$ & 2.43 & 1.02 & & & \\
\hline \multirow[t]{3}{*}{ Mentor } & Social sciences & 2.89 & 1.00 & 7 & \multirow[t]{3}{*}{5.341} & \multirow[t]{3}{*}{0.000} \\
\hline & Humanities & 2.48 & 0.90 & 296 & & \\
\hline & $\begin{array}{l}\text { Engineering } \\
\text { sciences }\end{array}$ & 2.08 & 0.63 & & & \\
\hline
\end{tabular}




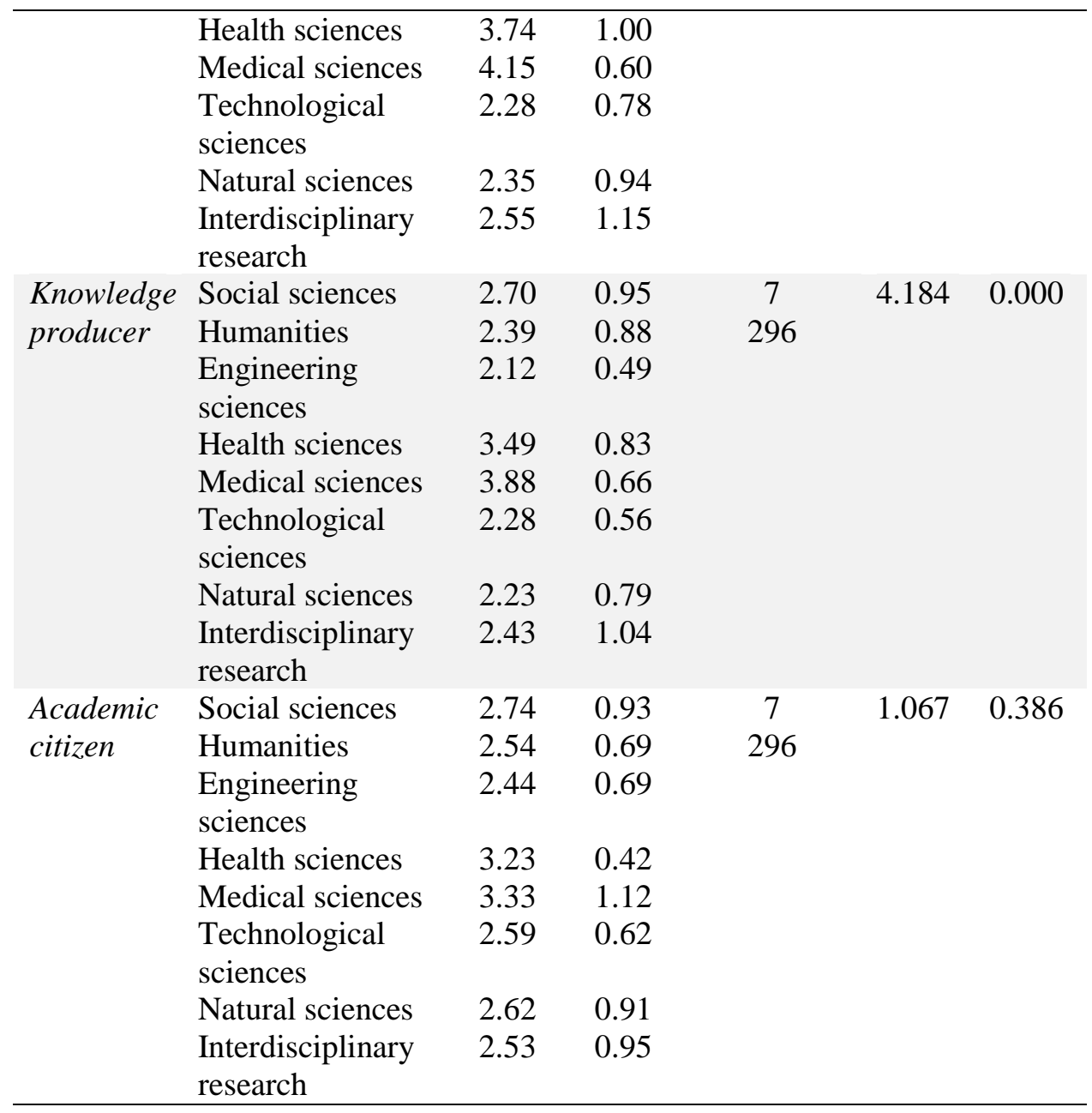

The dispersive analysis of blocked data indicated distinguished opinions of the researchers representing the humanities, technological and natural sciences (see Table 7). 
Table 7

Research fields

\begin{tabular}{lccccccccc}
\hline Field & Quantity & \multicolumn{4}{c}{ Sphericity measurement } & \multicolumn{3}{c}{ Mean equals } \\
\hline & & $\frac{\text { Mauchly's }}{\underline{\mathrm{W}}}$ & $\chi^{2}$ & $\underline{\mathrm{df}}$ & $\underline{\mathrm{p}}$ & $\underline{\mathrm{F}}$ & $\underline{\mathrm{df}}$ & $\underline{\mathrm{P}}$ \\
& & & & & & & & \\
Social sciences & 152 & 0.199 & 218.027 & 14 & 0.000 & 2.003 & 2.725 & 0.119 \\
Humanities & 40 & 0.100 & 78.392 & 14 & 0.000 & 3.280 & 2.722 & 0.028 \\
Engineering & 11 & 0.021 & 31.451 & 14 & 0.006 & 1.837 & 2.160 & 0.181 \\
sciences & & & & & & & & \\
Health sciences & 15 & 0.000 & - & 14 & - & 1.322 & 1.597 & 0.320 \\
$\begin{array}{l}\text { Medical } \\
\text { sciences }\end{array}$ & 13 & 0.000 & - & 14 & - & 4.249 & 1.359 & 0.140 \\
$\begin{array}{l}\text { Technological } \\
\text { sciences }\end{array}$ & 47 & 0.275 & 55.658 & 14 & 0.000 & 7.788 & 3.465 & 0.000 \\
$\begin{array}{l}\text { Natural sciences } \\
\text { Interdisciplinary }\end{array}$ & 12 & 0.036 & 26.904 & 14 & 0.024 & 3.966 & 2.622 & 0.022 \\
research & 14 & 0.124 & 23.147 & 14 & 0.063 & 0.258 & 5 & 0.934 \\
\hline
\end{tabular}

The researchers representing both humanities and technological or natural sciences dedicated the highest estimate for the role of an academic citizen. The representatives of humanities evaluated academic duty and the mentor's role lower. Meanwhile, the representatives of technological sciences devoted the second place for the role of a critic. Evaluation provided by the representatives of natural sciences indicated the importance of the mentor's role in the second place. The lowest evaluations in all researcher fields referred to academic freedom. According to the researchers representing humanities, only 0.01 higher medium was obtained by evaluating the role of a critic. The researchers representing technological sciences evaluated academic duty and the roles of a mentor and a knowledge producer equally.

The method of two-way dispersive analysis was applied in order to compare the roles according to the factors within the pairs (gender and research field; research field and experience in higher education institution). Though statistically significant differences regarding general interaction of factors were not determined (in all cases $\mathrm{p}>0.05$ ).

Evaluating the differences between statistically significant means by applying the repeated measures ANOVA, statistically significant deviations were derived 


\section{Acta Technologica Dubnicae \\ volume 6, 2016, issue 3}

(sphericity: Mauchly's $\mathrm{W}=0.002, \chi 2=1714.727, \mathrm{df}=54, \mathrm{p}=0.000$, mean equals: $\mathrm{F}=17.006, \mathrm{df}=4.112, \mathrm{p}=0.000$ ).

Correlation analysis between distinguished minor roles' descriptions revealed that the participation of researchers in society debates and public policy correlates with all the remaining roles of researchers very weakly or weakly. The strongest correlation with all roles referred to academic duty, a critic, personal development, and acting in one research field.

Neither age, nor work experience in higher education institution affected the statistically significant differences ( $>0.05$ referring to all the roles). Distribution of the Ph.D. dissertations according to the defence period till 1990, from 1990 to 2000 year, and the subsequent period didn't reveal statistically significant differences either ( $p>0.05$ referring to all roles).

If a mean comparison of the roles being grouped as "major" did not differ in the female group, then the roles being grouped as "minor" pointed out the statistically significant differences between both males and females (sphericity for female: Mauchly's W=0.001, $\chi 2=1260.029, \mathrm{df}=54, \mathrm{p}=0.000$, mean equals: $\mathrm{F}=7.071, \mathrm{df}=3.634, \mathrm{p}=0.038$; sphericity for male: Mauchly's $\mathrm{W}=0.003$, $\chi 2=529.842, \mathrm{df}=54, \mathrm{p}=0.000$, mean equals: $\mathrm{F}=13.097, \mathrm{df}=4.827, \mathrm{p}=0.000$ ).

While considering ANOVA and analysing evaluations being provided by the representatives from different scientific fields, it was determined that statistically significant differences do not refer to the activities such as „Scientists' activity implementing interdisciplinary research" nor "Participation in society debates and public policy" $(\mathrm{p}>0,05)$. In all other cases, the differences were statistically significant. Namely, high estimates were attributed to the representatives of health sciences and medical sciences: the representatives of medical sciences presented the highest estimates for all the roles. Health sciences' representatives appreciated scientific performance application for public interest at the highest level. In many cases the lowest estimates were provided by the representatives of engineering sciences.

The representatives of social sciences mostly appreciated freedom in association to inclusion, support and assistance, meantime, the lowest estimate was given to the ability to follow certain rules. The representatives of humanities, technological sciences and natural sciences preferred to evaluate the participation in society debates and public policy at the highest estimate, while the lowest estimates referred to following norms and academic freedom with the reference to new ideas, opinions, and actions. 


\section{Acta Technologica Dubnicae \\ volume 6, 2016, issue 3}

\section{Discussion}

The findings reported that female researchers' evaluations were higher in all cases regarding their roles in higher education. These results could be explained by the fact that female researchers could perceive their roles as the possibility for developing scientific self-confidence (Giugno et al., 2015) and/or proving intellectual capabilities of the female within the higher education area (Georgeta, 2014). This empirical fact adds the value to the understanding that knowledge and skills are related to the wealth of society (Macfarlane, 2007).

In the particular research study, the highest estimates were given to the roles by the researchers representing medical sciences. These findings could be interpreted as medical researchers' interest in performing their roles within higher education on the highest performance level (standard) (Clark \& Smith, 2003). This empirical fact reveals that medical researchers implement intellectual leadership through all their roles' performance on equal value (Myint et al., 2006). It could be also interpreted as medical researchers' wish to dedicate their time for all roles' performance in order to become intellectual leaders at universities and/or colleges. This empirical fact is not related to gender or work experience within a particular discipline (Paice et al., 2000).

Findings of the research revealed that the lowest estimates for the diverse roles in higher education were provided by the researchers from engineering sciences. Why are these results contrasting with the medical researchers' opinions? Considerations regarding these findings could be focused on the purposes of training medical and engineering professionals in higher education institutions. Medical professionals are trained to take responsibility in all stages of the process - from starting till ending - and this is related to health outcomes of the patient (Fong Ha \& Longnecker, 2010). Medical professionals also relate their activity (work) outcomes to the social interactions regarding patients, their relatives and colleagues (physicians, nurses and other professionals) as team members. They are responsible for their own (as a team member's) results and all the team work outcomes (Torpey, 2015). However, engineering professionals are mostly focused on the intermediate phase and the product for which they are responsible. Other stages of the process are mostly the responsibility of other specialists. Here, the social interaction is not the core of the working process and the responsibility is transferred in different phases to different professionals (Why so few? Women in Science, Technology, Engineering and Mathematics, 2010). The findings of the current research could be seen through the training of future professionals, development and internalisation of professional values where the core focus is on the responsibility for own and the others' work results (Pinfield \& Middleton, 2016). 


\section{Acta Technologica Dubnicae \\ volume 6, 2016, issue 3}

Academic freedom is a crucial element for a free and civil society, but we must be able to have open discussions for it to flourish. If you can't express yourself in a university campus, doing so off-campus is usually even harder. Where academic freedom is restricted, it is a measure of the limits of free speech in the society at large (Timms, 2016). The findings from this particular research revealed that the lowest evaluation in all research fields refers to academic freedom. The estimates regarding academic duty are significantly higher compared to those that represent academic freedom. So, findings showed that for researchers, academic duty is more important than academic freedom, without reference to gender, research area, or years of work experience in higher education institutions. The findings of the particular research did not answer the question, "Why researchers value more academic duty than academic freedom?". Then this empirical fact can be interpreted by speculating with a variety of opinions and considerations. A lot of research participants are representatives who graduated from higher education institutions during the "Soviet times", where academic freedom was not the object of the researchers' work reality. Thus, this aspect could be the factor, which influenced the research participants to be more focused on academic duty than on academic freedom.

In contemporary higher education, the focus on academic duty is stronger than on academic freedom, in other words, the space of academic freedom in higher education is shrinking because of a lot of academic and non-academic duties and responsibilities, which are required by the global higher education area and the global academic market (Olivas, 2011). On the other hand, academic freedom implies that research and creative interests are a matter of individual choice, not a subject to directive. That does not assign complete license; some limitations are consistent with academic freedom. Faculty research and creative choices are subjects to the law, professional responsibility for openness and accountability, and the ethical principle that the researcher must avoid imposing undue harm (Duvall et al., 2004). It is therefore likely that research participants included their own understanding into academic duty and academic freedom, which is not possible to study deeper without a qualitative study (in the future).

\section{Conclusions}

Intellectual leadership is the scope of challenging processes regarding developing, designing, creating, defining, ensuring, critiquing, teaching, instructing, researching, mentoring, enabling questioning, generating, envisioning, advocating, encouraging, re-imagining, managing, representing, counseling, achieving, evaluating, acting, and providing. The general components refer to ideas, values, understandings, solutions, beliefs, visions, knowledge, approaches, purposes, and actions. These aspects must be acknowledged through collectively shared understanding within the academic 


\section{Acta Technologica Dubnicae \\ volume 6, 2016, issue 3}

community and generated contextually for universities' and/or colleges' development in higher education with a focus on the academic duty and freedom. For researchers, intellectual leadership covers a wide range of aspects in association to their roles at universities and/or colleges.

The demographic factors that are worth to take into account when studying researchers' roles within intellectual leadership in higher education are gender and research areas. Years of work experience in higher education and the year of $\mathrm{Ph} . \mathrm{D}$. defence are not the factors, which are meaningfully related to the role performance, academic duty and academic freedom of researchers by implementing intellectual leadership in higher education.

\section{References}

Altbach, P., Reisberg, L., \& Rumbley, L. E. (2009). Trends in global higher education: Tracking an academic revolution. France: UNESCO.

Blackmore, P., \& Blackwell, R. (2006). Strategic leadership in academic development. Studies in Higher Education, 31(3), 373-387.

Cambridge Dictionaries Online (2016). Retrieved from http://dictionary.cambridge.org/dictionary/english/researcher

Clark, J., \& Smith, R. (2003). BMJ Publishing Group to launch an international campaign to promote academic medicine. British Medical Journal, 327(7422), 1001-1002.

Dealtry, R. (2001). Managing intellectual leadership in corporate value. Journal of Workplace Learning, 13(3), 119-124.

Dictionary.com (2016). Retrieved from http://www.dictionary.com/ browse/researcher

Duvall, R., Grotevant, H., Gunnar, M., Guyotte, R., Hardy, R., Mackenzie, Th., Pui, D., Schmidt, L., \& Ecklein, S. (2004). Report of the task force on academic freedom. Univeristy of Minnesota. Retrieved from http://usenate.umn.edu/fcc/ acadfreedomreport.html

Fong Ha, J., \& Longnecker, N. (2010). Doctor-patient communication: a review. The Ochsner Journal, 10(1), 38-43.

Fowler, J. (1981). Stages of faith: The psychology of human development and the quest for meaning. New York, NY: Harper \& Row.

Georgeta, I. (2014). Understanding the role of organizational factors in shaping the research careers of women academics in higher education. Journal of New Approaches in Educational Research, 3(2), 59-66.

Grayson, L. (2016). The roles of a professor. Chron. Retrieved from http://work.chron.com/roles-professor-1001.html

Havergal, Ch. (2015). Is 'academic citizenship' under strain? Times Higher Education: World University Rankings. Retrieved from https://www.timeshighereducation.com/features/is-academic-citizenship- 


\section{Acta Technologica Dubnicae}

volume 6, 2016, issue 3

under-strain/2018134.article

Justice, M. C., \& Scott, J. (2012). Institutional factors promoting community college fundraising. Administrative Issues Journal, 2(3), Article 17. Retrieved from http://dc.swosu.edu/cgi/viewcontent.cgi?article=1199\& context=aij

Kennedy, B. D. (1997). Academic duty. Cambridge, MA: Harvard University Press.

Macfarlane, B. (2007). The academic citizen - The virtue of service in university life. London \& New York: Routledge, Taylor \& Francis Group.

Macfarlane, B. (2010). Roundtable. Exploring intellectual leadership. SRHE Annual Conference 'Where is the wisdom we have lost in knowledge?' Exploring meaning, identities and transformation in higher education (14-16 December, 2010). New Port, South Wales, United Kingdom. Retrieved from http://www.srhe.ac.uk/conference2010/abstracts/0308.pdf

Macfarlane, B. (2011). Professors as intellectual leaders: Formation, identity and role. Studies in Higher Education, 36(1), 57-73.

Macfarlane, B. (2012). Intellectual leadership in higher education: Renewing the role of the university professor. London: Routledge.

Macfarlane, B., \& Chan, R. Y. (2014). The last judgement: Exploring intellectual leadership in higher education through academic obituaries. Studies in Higher Education, 39(2), 294-306.

Myint, P. K., MacLullich, A. M. J., \& Witham, M. D. (2006). The role of research training during higher medical education in the promotion of academic medicine in the UK. Postgraduate Medical Journal, 82(973), 767-770.

Nickles, T. (2011). The role of religion and spirituality in counseling. California Polytechnic State University: College of Liberal Arts. Retrieved from http://digitalcommons.calpoly.edu/cgi/viewcontent.cgi?article=1024\&conte $\mathrm{xt}=\mathrm{psycdsp}$

Olivas, M. A. (2011). Academic freedom and academic duty. The Association of American Law Schools: Advancing Excellence in Law Education. Retrieved from https://www.aals.org/services/presidents-messages/ academic-freedom-academic-duty/

Paice, E., Aitken, M., Cowan, G., \& Heard, Sh. (2000). Trainee satisfaction before and after the Calman reforms of specialist training: questionnaire survey. British Medical Journal, 320(7238), 832-836.

Pinfield, S., \& Middleton, Ch. (2016). Researchers' adoption of an institutional central fund for open-access article-processing charges. A case study using innovation diffusion theory. SAGE Open. Retrieved from http://sgo.sagepub.com/content/6/1/2158244015625447 


\section{Acta Technologica Dubnicae \\ volume 6, 2016, issue 3}

Rossiter, D. G., Liu, J., Carlisle, S., \& Zhu, A.-X. (2015). Can citizen science assist digital soil mapping? Geoderma, 259(260), 71-80.

Rowley, D. J., \& Sherman, H. (2003). The special challenges of academic leadership. Management Decision, 41(10), 1058-1063.

Roy, A., Giovannini, F., Satterthwaite, D., \& Chaturvedi, B. (2008). Global norms and planning forms: The Millennium Development Goals towards an intellectual leadership: Rediscovering the role of the United Nations in the 21 st Century. The central role of local organizations in meeting the Millennium Development Goals (MDGs). The Story of Chintan. Planning Theory \& Practice, 9(2), 251-274.

Stevenson, H. (2012). Teacher leadership as intellectual leadership: creating spaces for alternative voices in the English school system. Professional Development in Education, 38(2), 345-360.

Sugarman, S. D. (2005). Conflicts of interest in the roles of the university Professor. Theoretical Inquiries in Law, 6. Retrieved from http://works.bepress.com/stephen_sugarman/9/

Tavakol, M., \& Dennick, R. (2011). Making sense of Cronbach's alpha. International Journal of Medical Education, 2, 53-55.

Taylor, L., \& Parsons, J. (2011). Improving student engagement. Current Issues in Education, 14(1). Retrieved from http://cie.asu.edu/

The Free Dictionary by Farlex (2016). Retrieved from http://www.thefreedictionary.com/researcher

Theall, M. (2002). Leadership in faculty evaluation and development: some thoughts on why and how the meta-profession can control its own destiny. Invited address at the 82nd annual meeting of the American Educational Research Association. New Orleans: April 3. Retrieved from www.cedanet.com/meta/meta_leader.pdf

Theall, M., \& Arreola, R. A. (2003). The multiple roles of the college professor. Youngstown State University \& University of Tennessee Health Science Center. Retrieved from http://www.nea.org/home/34715.htm

Timms, J. (2016). Why is academic freedom important? Xindex. Retrieved from https://www.indexoncensorship.org/2016/04/academic-freedom-important/

Torpey, E. (2015). Same occupation, different pay: how wages vary. Career Outlook. United States Department of Labor, Bureau of Labor Statistics. Retrieved from http://www.bls.gov/careeroutlook/2015/article/wagedifferences.htm

Tseng, H. CH., Tung, H. L., \& Duan, Ch. H. (2010). Mapping the intellectual structure of modern leadership studies. Leadership \& Organization Development Journal, 31(1), 57-70.

Uslu, B., \& Arslan, H. (2015). Faculty's academic intellectual leadership: Predictive relations with several organizational characteristics of universities. Journal of Higher Education and Science, 5(2), 125-135.

Why so few? Women in Science, Technology, Engineering and Mathematics 


\section{Acta Technologica Dubnicae \\ volume 6, 2016, issue 3}

(2010). Washington, DC: AAUW. Retrieved from https://www.aauw.org/ files/2013/02/Why-So-Few-Women-in-Science-Technology-Engineeringand-Mathematics.pdf

Yamane, T. (1967). Statistics: An introductory analysis (2nd ed.). New York: Harper and Row.

Yielder, J., \& Codling, A. (2004). Management and leadership in the contemporary university. Journal of Higher Education Policy and Management, 26(3), 315-328.

Zydziunaite, V., Tandzegolskiene, I., \& Rutkiene, A. (2015). Considerations on a scientist's academic mission and roles in a higher education school. Acta Technologica Dubnicae, 5(2), 51-68. doi: 10.1515/atd-2015-0064

Zydziunaite, V., Butautaite, V., Rutkiene, A., \& Tandzegolskiene, I. (2015). Multilayered considerations on the concept of "leadership": conceptual views in psychology, management and education. European Scientific Journal, 11(25), 17-28. 